\title{
PENGARUH MODEL PEMBELAJARAN INQUIRY TERHADAP KEMAMPUAN BERPIKIR KRITIS SISWA KELAS VA SDN 90 KENDARI
}

\author{
Noviana ${ }^{1)}$, La Anse ${ }^{2)}$ \\ 1) SDN 90 Kendari, Kendari, Indonesia \\ ${ }^{2)}$ Jurusan PGSD, Universitas Halu Oleo, Kendari, Indonesia \\ email: noviana097@gmail.com
}

\begin{abstract}
Abstrak: Penelitian ini bertujuan untuk mengetahui pengaruh model pembelajaran Inquiry terhadap kemampuan berpikir kirtis Siswa pada Tema Peristiwa dalam Kehidupan pembelajaran 3 dan 4 materi peristiwa kebangsaan masa penjajahan di kelas VA SD Negeri 90 Kendari. Jenis penelitian yang digunakan dalam penelitian ini adalah penelitian eksperimen. Penelitian ini telah dilaksanakan pada SD Negeri 90 Kendari. populasi dalam penelitian ini yaitu seluruh siswa kelas V Sekolah Dasar Negeri 90 Kendari Tahun ajaran 2018/2019. Teknik pengambilan sampel yang digunakan adalah total sampling. Oleh karena itu, sampel dalam penelitian ini yakni kelas VA sebagai kelas eksperimen dan kelas VB sebagai kelas kontrol. Teknik Pengumpulan data yang digunakan dalam penelitian ini berupa teknik pemberian tes. Analisis data dilakukan dengan menggunakan analisis deskriptif dan analisis inferensial. Hasil penelitian menunjukkan bahwa terdapat pengaruh penerapan model pembelajaran inquiry terhadap kemampuan berpikir kritis siswa pada tema Peristiwa dalam Kehidupan kelas VA SD Negeri 90 Kendari. Hal ini dapat dilihat dari nilai rata-rata posttest kemampuan berpikir kritis siswa pada tema Peristiwa dalam Kehidupan kelas VA SD Negeri 90 Kendari pada kelas eksperimen $=70,94$ dan kelas kontrol $=59,69$ maka kemampuan berpikir kritis siswa dengan penerapan model pembelajaran inquiry lebih tinggi dari pada rata-rata tes kemampuan berpikir kritis siswa dengan model pembelajaran konvensional.
\end{abstract}

Kata kunci: inquiry; kemampuan berpikir kritis

\section{THE INFLUENCE OF INQUIRY LEARNING MODEL ON CRITICAL THINKING ABILITY OF STUDENTS IN CLASS VA AT SDN 90 KENDARI}

\begin{abstract}
This research aimed to determine the effect of the Inquiry learning model on students' thinking skills in the Event Themes in learning life 3 and 4 material on the nationality of colonialism in the VA class of SD Negeri 90 Kendari. The type of research used in this study is experimental research. This research was conducted at SD Negeri 90 Kendari. the population in this study were all fifth grade students of Public Elementary School 90 Kendari 2018/2019 academic year. The sampling technique used is total sampling. Therefore, the sample in this study was the VA class as the experimental class and the VB class as the control class. The data collection technique used in this study is in the form of a test giving technique. Data analysis was carried out using descriptive analysis: Descriptive analysis and Inferential analysis. The results of the study showed that there was an effect of the application of the inquiry learning model on students' critical thinking skills in the theme of events in the class life of VA SD Negeri 90 Kendari. This can be seen from the average posttest value of students 'critical thinking skills in the Event theme in the Life class VA SD Negeri 90 Kendari in the experimental class = 70.94 and the control class $=59.69$ then the students' critical thinking ability with the application of the inquiry learning model is more higher than the average test of students' critical thinking skills with conventional learning models.
\end{abstract}

Keywords: Inquiry; critical thinking skills 


\section{Pendahuluan}

Masalah utama dalam pembelajaran pada pendidikan dewasa ini adalah masih rendahnya daya serap peserta didik. Hal ini tampak dari rerata hasil belajar peserta didik yang senantiasa masih memprihatinkan. Prestasi ini tentunya merupakan hasil kondisi pembelajaran yang bersifat konvensional dan tidak menyentuh ranah dimensi peserta didik itu sendiri. Dalam arti yang lebih substansional, bahwa proses pembelajaran hingga dewasa ini masih memberikan dominasi guru dan tidak memberikan akses bagi anak didik untuk berkembang secara mandiri melalui penemuan dalam proses berpikirnya (Henok Siagian, 2017, p.47-48)

Dari hasil observasi dan wawancara dengan Ibu Rahmawati guru kelas VA SD Negeri 90 Kendari menyatakan bahwa pemahaman siswa terhadap pelaksanaan pembelajaran masih dianggap rumit, maksudnya tingkat pemahaman siswa dari materi pembelajaran masih kurang sehingga mengalami kesulitan menyelesaikan soal, hal ini merupakan indikator kemampuan interpretasi atau mengenal masalah masih kurang. Kesulitan yang sering ditemui guru pada saat mengajar yaitu pemahaman bahasa dimana di sini siswa kurang memahami apa yang diucapkan guru meskipun pada saat mengajar selalu dikaitkan dengan contoh konkritnya, hal tersebut merupakan indikator kemampuan menganalisis siswa masih rendah. Siswa kesulitan menyelesaikan soal-soal cerita dalam pelajaran, hal ini dapat menunjukkan bahwa indikator kemampuan mengevaluasi siswa masih kurang, akibatnya kemampuan berpikir kritis siswa masih rendah. Menurut Hendracipta, dkk (2017, p. 216) menjelaskan bahwa berpikir kritis adalah suatu kegiatan melalui cara berpikir tentang ide atau gagasan yang berhubungan dengan konsep yang diberikan atau masalah yang dipaparkan. Menurut Nur'Azizah (2016, p.52) kemampuan berpikir kritis merupakan kemampuan yang berfokus pada hal-hal yang masuk akal dan reflektif, sehingga mampu menarik kesimpulan untuk mempercayai sesuatu dan melaksanakan apa yang diputuskan. Lastriningsih (2017, p.69) mengemukakan bahwa aspek kemampuan berpikir kritis meliputi mengidentifikasi masalah, menganalisis, dan menyimpulkan. Mengidentifikasi masalah berarti mampu merumuskan pokok-pokok permasalahan. Menganalisis berarti mampu menghubungkan informasi yang relevan dalam penyelesaian suatu masalah. Sedangkan Menyimpulkan berarti mampu menyusun kesimpulan berdasarkan hasil analisis. Menurut Fahruddin Faiz dalam Sanderayanti (2015, p.226) menjelaskan bahwa kemampuan berpikir kritis mempunyai lima jenis keterampilan, yaitu : (1) Keterampilan menganalisa, (2) Keterampilan melakukan sintesa, (3) Keterampilan memahami dan memecahkan masalah, (4) Keterampilan menyimpulkan, (5) Keterampilan mengevaluasi dan menilai.

Dalam proses pembelajaran guru sering menggunakan metode pembelajaran namun pembelajaran yang tidak menekankan pada upaya pengembangan keterampilan berpikir kritis mengkondisikan siswa ke dalam belajar hafalan. sehingga peneliti menyimpulkan bahwa pembelajaran itu menjadi kurang bermakna dan siswa mudah melupakan materi yang telah diajarkan sebelumnya.

Berdasarkan dokumen guru wali kelas VA tahun 2017/2018 di SD Negeri 90 Kendari, diperoleh informasi bahwa selama proses pembelajaran rata-rata hasil ulangan siswa belum mencapai Kriteria Ketuntasan Minimal (KKM) yaitu 74, persentase ketuntasanya hanya $66 \%$ dari 32 siswa, hanya 21 orang dari 32 siswa yang mencapai KKM dan 11 orang siswa tidak mencapai KKM. Rendahnya hasil belajar siswa tidak terlepas dari proses pembelajaran yang dilakukan oleh guru.

Menyikapi fenomena di atas perlu dilakukan upaya untuk memperbaiki dan meningkatkan hasil belajar siswa kelas V SD Negeri 90 Kendari melalui model pembelajaran yang inovatif. Salah satu model pembelajaran inovatif adalah melalui model pembelajaran inquiry. Model pembelajaran inquiry adalah suatu kegiatan pembelajaran yang menekankan 
pada proses berpikir kritis dan analitis untuk mencari dan menemukan sendiri jawaban dari suatu masalah yang dipertanyakan. Siswa didorong untuk aktif mencari jawaban atas masalah-masalah yang dihadapinya dan menarik kesimpulan sendiri melalui proses berpikir ilmiah yang kritis, logis, dan sistematis. Siswa tidak lagi bersifat dan bersikap pasif, menerima dan menghafal pelajaran dari gurunya. Suhada (2017, p.15) menjelaskan bahwa model pembelajaran inquiry adalah rangkaian kegiatan pembelajaran yang menekankan pada keaktifan siswa untuk memiliki pengalaman belajar dalam menemukan konsep - konsep materi berdasarkan masalah yang diajukan Menurut Kunandar dalam Hanifah (2017, p.93) pembelajaran inquiry adalah kegiatan pembelajaran dimana siswa didorong untuk belajar melalui keterlibatan aktif mereka sendiri dengan konsep-konsep dan prinsip-prinsip, dan guru mendorong siswa untuk memiliki pengalaman dan melakukan percobaan yang memungkinkan siswa menemukan prinsip-prinsip untuk diri mereka sendiri. Model pembelajaran inquiry adalah rangkaian kegiatan pembelajaran yang menekankan pada keaktifan siswa untuk memiliki pengalaman belajar dalam menemukan konsep - konsep materi berdasarkan masalah yang diajukan (Lastriningsih, 2017, p.15).

Penelitian yang pernah dilakukan Astuti, (2018) dengan judul penelitian "Pengaruh Model Pembelajaran Inquiry Terhadap Kemampuan Berpikir Kritis Siswa pada Tema Organ Gerak Hewan dan Manusia Kelas Vc SDN 01 Baruga" Hasil penelitian ini menunjukkan bahwa kemampuan berpikir kritis siswa pada tema Organ Gerak Hewan dan Manusia menggunakan model inquiry pokok bahasan kondisi geografis negara Indonesia menunjukkan adanya peningkatan. Hal ini dapat dilihat dari nilai rata-rata posttes kemampuan berpikir kritis peserta didik yaitu kelas eksperimen $=67.3$ dan kelas kontrol $=42.9$, maka kemampuan berpikir kritis dengan model pembelajaran inquiry lebih tinggi dari pada rata-rata tes kemampuan peserta didik dengan model pembelajaran konvensional. Hal ini dibuktikan dengan hasil penelitian yang dihitung menggunakan bantuan SPSS 16. Hasilnya adalah = $\mathrm{t}_{\text {hitung }} 2.472>\mathrm{t}_{\text {tabel }}$, 1.992. Jadi dalam penelitian ini hipotesis $\mathrm{H}_{0}$ diterima dan $\mathrm{H} 1$ ditolak. Dengan demikian penerapan pembelajaran inquiry sangat membantu peserta didik dalam meningkatkan kemampuan berpikir kritis dalam proses pembelajaran pada tema Organ Gerak Hewan dan Manusia di kelas Vc.

Penelitian yang relevan pernah dilakukan oleh Hani Nur'Azizah, Asep Kurnia Jayadinata, Diah Gusrayani (2016) dengan judul penelitian "Pengaruh Model Pembelajaran inquiry Terhadap Kemampuan Berpikir Kritis Siswa Pada Materi Energi Bunyi" Hasil penelitian menunjukkan: model pembelajaran inquiry dan pembelajaran konvensional dapat meningkatkan kemampuan berpikir kritis siswa pada materi energi bunyi secara signifikan dan peningkatan kemampuan berpikir kritis dengan perlakuan model pembelajaran inquiry lebih baik secara signifikan daripada pembelajaran konvensional. Siswa merespon positif dan guru melakukan kegiatan positif dalam pembelajaran menggunakan model pembelajaran inquiry, namun, guru masih kurang optimal dalam mengelola kelas.

Berdasarkan latar belakang yang dikemukakan di atas maka penulis tertarik untuk melaksanakan penelitian tentang "Pengaruh Model Pembelajaran Inquiry Terhadap Kemampuan Berpikir Kritis Siswa pada Tema Peristiwa dalam Kehidupan Kelas V SD Negeri 90 Kendari."

\section{Metode}

Penelitian ini menggunakan desain penelitian pretest-posttest control group design. populasi dalam penelitian ini yaitu seluruh siswa kelas V Sekolah Dasar Negeri 90 Kendari Tahun ajaran 2018/2019. Sampel dalam penelitian ini yakni kelas VA sebagai kelas eksperimen dan kelas VB sebagai kelas kontrol. 
Teknik Pengumpulan data yang digunakan dalam penelitian ini berupa teknik pemberian tes yang diberikan pada kelas eksperimen dan kelas kontrol dalam bentuk tertulis. Teknik analisis data pada penelitian ini menggunakan program computer SPSS for windows dengan tingkat kepercayaan $95 \%$.

\section{Hasil}

Sebelum diberikan perlakuan, siswa terlebih dahulu diberikan pretest untuk mengetahui kemampuan awal siswa. Nilai pretest pada kelas eksperimen dan kelas kontrol disajikan dalam bentuk diagram berikut

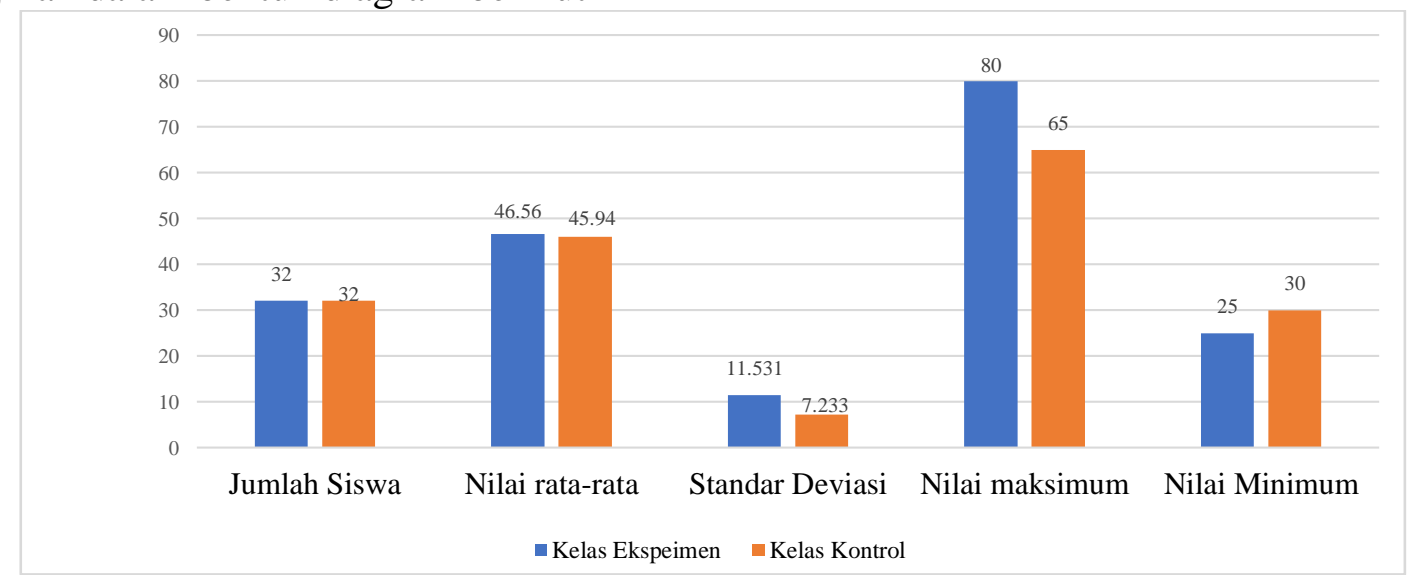

Gambar 1. Diagram Nilai Pretest Pada Kelas Eksperimen dan Kelas Kontrol

Berdasarkan grafik di atas dapat dideskripsikan bahwa jumlah siswa pada kelas eksperimen sebanyak 32 siswa. Hasil pretest kemampuan berpikir kritis siswa bahwa ratarata kelas eksperimen adalah 46.56, standar deviasi=11.531, nilai maksimum sebesar 80 dan nilia minimum sebesar 25. Sedangkan hasil pretes kelas control dengan jumlah siswa sebanyak 32 siswa, nilai rata-rata $=45.94$, standar deviasi $=7.333$, nilai maksimum sebesar 65 dan nilai minimum sebesar 30. Nilai posttes pada akelas eksperimen dan kelas kontrol disajikan pada diagram berikut:

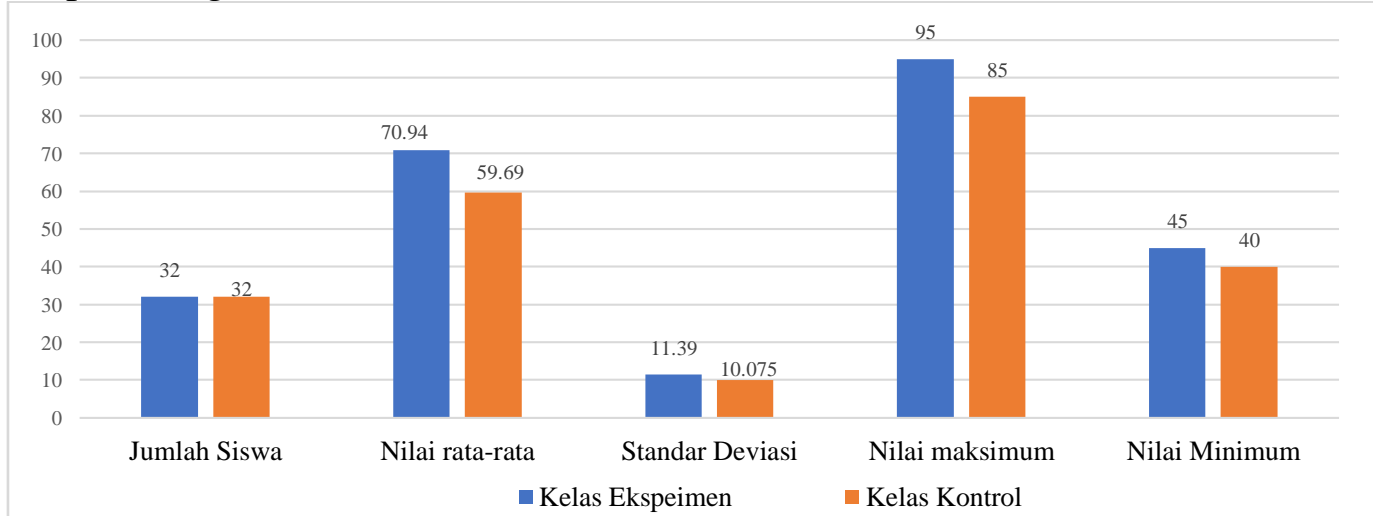

Gambar 2. Diagram Nilai Posttest Pada Kelas Eksperimen dan Kelas Kontrol

Berdasarkan grafik di atas dapat dideskripsikan bahwa jumlah siswa pada kelas eksperimen sebanyak 32 siswa. Hasil postes kemampuan berpikir kritis siswa bahwa ratakelas eksperimen adalah 70.94, standar deviasi $=11.390$, nilai maksimum sebesar 95 dan nilai minimum sebesar 45. Sedangkan hasil postes kelas kontrol dengan jumlah siswa sebanyak 32 siswa, nilai rata-rata $=59.69$, standar deviasi $=10.075$, nilai maksimum sebesar 85 dan nilai minimum sebesar 40 . 
Data yang diperoleh akan dianalisis untuk menguji hipotesis. Namun sebelumnya dilakukan uji normalitas data. Berdasarkan hasil uji normalitas data statistik uji KolmogorovSmirnov dengan bantuan SPSS 23.0 for Windows Evaluation Version pada kelas eksperimen diperoleh nilai $\mathrm{p}=0,957$. Karena nilai $\mathrm{p}>\alpha$ atau $0,957>0,05=$ maka $\mathrm{H}_{1}$ diterima, hal ini berarti bahwa data yang diperoleh beridistribusi normal. Uji normalitas data menggunakan statistik uji Kolmogorov-Smirnov dengan bantuan SPSS 23.0 for Windows Evaluation Version pada kelas control diperoleh nilai $\mathrm{p}=0,992$. Karena nilai $\mathrm{p}>\alpha$ atau $0,992>0,05=$ maka $\mathrm{H}_{1}$ diterima, hal ini berarti bahwa data yang diperoleh beridistribusi normal.

Uji homogenitas variansi (variance) sangat diperlukan sebelum kita membandingkan dua kelompok atau lebih, agar perbedaan yang ada bukan disebabkan oleh adanya perbedaan data dasar (ketidak homogenan kelompok yang dibandingkan). Berdasarkan hasil perhitungan SPSS 23.0 for Windows Evaluation Version, diperoleh nilai signifikansi kemampuan berpikir kritis siswa pada kelas eksperimen dan kelas kontrol adalah sebesar $0.061>0.05$. Artinya data kemampuan kemampuan berpikir kritis siswa mempunyai varians yang sama atau homogen.

Uji Hipotesis penelitian menggunakan skor $N$-Gain pada kelompok eksperimen dan kelompok kontrol. Karena data skor $N$-Gain pada kelas eksperimen dan data skor $N$-Gain pada kelas kontrol berdistribusi normal, maka pengujian hipotesis yang digunakan adalah uji-t berpasangan (uji paired t-test) dengan menggunakan skor $\mathrm{N}$-Gain. Pengujian hipotesis dilakukan dengan menggunakan uji paired t-test dengan bantuan SPSS 23.0 for Windows Evaluation Version.

Berdasarkan hasil perhitungan SPSS 23.0 for Windows Evaluation Version, diperoleh nilai signifikansi $\rho<\alpha$ atau $0.003<0.05$ maka dapat disimpulkan bahwa terdapat pengaruh penerapan model pembelajaran inquiry terhadap kemampuan berpikir kritis siswa pada tema Peristiwa dalam Kehidupan kelas VA SD Negeri 90 Kendari.

\section{Pembahasan}

Berdasarkan data pretest menunjukkan rata-rata kelompok eksperimen sebesar 46,56 lebih tinggi dibanding kelompok kontrol sebesar 45,94. Hal tersebut menunjukkan bahwa input kelompok eksperimen lebih tinggi dari pada input kelompok kontrol, tetapi rata-rata kelompok eksperimen dan kontrol masih sama-sama rendah. Rendahnya rata-rata pretest ini disebabkan materi yang diujikan belum diajarkan kepada siswa, jadi mereka menjawab pertanyaan sesuai dengan pengalaman siswa dalam kehidupan sehari-hari. Perbedaan nilai rata-rata pretest antara kelompok eksperimen dan kontrol tidak berpengaruh terhadap hasil uji homogenitas pretest kelompok eksperimen dan kelompok kontrol yang menyatakan bahwa kedua kelompok homogen.

Selain itu, hasil posttest pada kelompok eksperimen dan kontrol, nilai terendah kelompok eksperimen 45 dan nilai terendah kelompok kontrol adalah 40. Perbedaan hasil belajar antara kelompok eksperimen dan kelompok kontrol disebabkan karena kelompok eksperimen menggunakan model pembelajaran inquiry, dimana dalam pembelajarannya siswa terlibat langsung sehingga termotivasi untuk belajar. Selain itu, siswa diberi kesempatan untuk berpartisipasi dalam pembelajaran dan guru hanya membimbing siswa.

Hal ini sejalan dengan pengertian inquiry menurut Henok Siagian (2017, p.48) yang menyatakan bahwa inquiry adalah cara berpikir, belajar, dan mengajar yang mengubah budaya sekolah menjadi komunitas penyelidikan kolaboratif. inquiry (guided inquiry) merupakan salah satu model pembelajaran yang dirancang untuk mengajarkan konsep dan hubungan antar konsep. Ketika menggunakan model pembelajaran ini, guru menyajikan contoh-contoh pada siswa, memandu siswa saat berusaha menemukan pola-pola dalam contoh-contoh tersebut, dan memberikan semacam penutup ketika siswa telah mampu 
mendeskripsikan gagasan yang diajarkan oleh guru. Sedangkan kelompok kontrol dalam pembelajarannya masih bersifat konvensional (demonstrasi) guru yang melakukan, menunjukkan dan memperlihatkan suatu proses, sehingga siswa kurang paham terhadap apa yang dijelaskan oleh guru. Selain itu metode demonstrasi kurang efektif bila tidak diikuti dengan sebuah aktivitas siswa sendiri yang melakukan dan menjadikan aktivitas itu pengalaman yang berharga. Dewei dalam Dimyati dan Mudjiono (2002, p.12) bahwa belajar yang baik, dilakukan oleh siswa yang aktif baik secara individual maupun secara kelompok.

Berdasarkan perbandingan hasil kemampuan berpikir kritis siswa rata-rata posttest siswa yang diajar dengan model pembelajaran inquiry terhadap posttest siswa yang belajar dengan cara konvensional (demonstrasi) dapat disimpulkan bahwa kelompok yang diajar dengan model pembelajaran inquiry lebih baik dari pada kelompok yang yang diajar dengan metode demonstrasi. Artinya terdapat pengaruh penerapan model pembelajaran inquiry terhadap kemampuan berpikir kritis siswa pada tema peristiwa dalam kehidupan kelas VA SD Negeri 90 Kendari.

Berdasarkan perhitungan N-Gain kelompok eksperimen dan kelompok kontrol, diperoleh nilai rata-rata kelompok eksperimen lebih besar dari pada nilai rata-rata kelompok kontrol. Nilai rata-rata $\mathrm{N}$-Gain pada kelompok eksperimen sebesar 0,43 termasuk dalam kategori sedang dan nilai rata-rata pada kelompok kontrol sebesar 0,25 termasuk dalam kategori kurang. Peningkatan hasil belajar kelompok eksperimen sebesar 0,43 lebih tinggi dibanding kelompok kontrol sebesar 0,25 karena dalam kelompok eksperimen pembelajarannya menggunakan inquiry, dimana dalam pembelajarannya siswa aktif dalam kegiatan belajar serta dapat melakukan aktifitas ilmiah dalam menemukan konsep yang sedang dipelajari. Pembelajaran inquiry ini salah satunya melakukan pengamatan. Pada kegiatan pengamatan siswa merencanakan sendiri untuk memecahkan masalah, guru memfasilitasi penyelidikan dan mendorong siswa mengungkapkan atau membuat pertanyaanpertanyaan yang membimbing mereka untuk penyelidikan lebih lanjut. Model belajar inquiry dibagi ke dalam 5 tahapan, yang mana lima tahapan tersebut sangat menentukan berhasil atau tidaknya pelaksanaan model ini.

Pada pertemuan pertama dalam pelaksanaan penelitian masih terdapat beberapa kendala dalam proses pembelajaran, diawali dengan peneliti memberi penjelasan mengenai model pembelajaran inquiry dan petunjuk penggunaan Lembar Kerja Peserta Didik (LKPD), namun masih banyak siswa yang bingung sehingga mereka banyak bertanya kepada peneliti apa yang akan mereka tuliskan dalam LKPD tersebut. Selain itu, kendala lainnya yang dialami peneliti adalah pengetahuan siswa terhadap materi sebelumnya/materi prasyarat siswa masih rendah, padahal pada model pembelajaran inquiry mengharuskan siswa untuk mengumpulkan informasi dari berbagai sumber yang salah satunya ada di materi sebelumnya/materi prasyarat.

Pada pertemuan selanjutnya, siswa mulai memahami dan terbiasa dengan model pembelajaran inquiry, siswa mulai belajar mengingat materi sebelumnya, serta mampu mengisi arahan-arahan yang ada dalam LKPD secara berkelompok. Peningkatan tersebut dicapai dari pembelajaran sejak hari pertama penelitian. Meskipun masih ada beberapa siswa yang masih kurang konsentrasi dalam belajar.

Pada tahap pertama model pembelajaran inquiry, Orientasi peserta didik kepada masalah, peneliti menyajikan masalah pada peserta didik untuk mengetahui dan menggali pengetahuan awal siswa yang berkaitan dengan masalah. Setelah itu tahap yang kedua adalah mengorganisasikan siswa untuk belajar, pada langkah ini siswa dibagi kedalam kelompok dan memberi kesempatan kepada siswa untuk berdiskusi. Pada tahap ini peneliti memberikan LKPD kepada kelompok yang berisi masalah yang berkaitan dengan materi yang dipelajari. Pada tahap ketiga yaitu membimbing penyelidikan individu maupun 
kelompok, siswa dituntut untuk mendiskusikan masalah yang ada pada LKPD agar ketahui pemecahan masalahnya. Peneliti membimbing siswa memahami masalah, membantu siswa untuk mengumpulkan informasi dari berbagai sumber informasi yang dibutuhkan untuk dapat menyelesaikan masalah. Tahapan selajutnya yaitu mengembangkan dan menyajikan hasil karya. Pada tahap ini siswa mempresentasikan hasil diskusi dengan teman kelompoknya, siswa bertukar pendapat tentang hasil diksusi yang telah dilakukannya dengan teman kelompoknya. Tahapan kelima yaitu menganalisis dan mengevaluasi proses pemecahan masalah. Pada tahap ini siswa mengkaji ulang proses dan hasil pemecahan masalah yang telah dilakukan pada tahap sebelumnya.

Selanjutnya nilai rata-rata posttest kemampuan berpikir kritis siswa kelas eksperimen 70,94 dan kelas kontrol 59,69. Nilai rata-rata posttest kemampuan berpikir kritis siswa kelas eksperimen lebih besar dari pada kelas kontrol. Dengan demikian dapat disimpulkan bahwa model pembelajaran inquiry lebih berpengaruh terhadap kemampuan berpikir kritis siswa. Secara umum adanya perbedaan hasi belajar antara kelas eksperimen dan kelas kontrol dimunkinkan karena dalam pembelajaran inquiry dikembangkan keterampilan siswa dalam bekerjasama, berkomunikasi, menemukan dan menyelesaikan masalah bersama dengan orang lain terkait pembelajaran sehingga memotivasi siswa untuk belajar dan akhirnya berpengaruh terhadap hasil belajar. Menurut Henok Siagian (2017, p.53) penggunaan model pembelajaran inquiry terintegrasi animasi flash dapat meningkatkan hasil belajar. Hal ini didukung oleh aktivitas siswa yang semakin meningkat pada setiap pembelajaran.

Berdasarkan hasil analisis hipotesis memberikan kesimpulan bahwa terdapat pengaruh penerapan model pembelajaran inquiry terhadap kemampuan berpikir kritis siswa pada tema Peristiwa dalam Kehidupan kelas VA SD Negeri 90 Kendari. Hal ini sejalan dengan yang dikemukakan Nurdyansyah, dan Fariyatul, (2016, p.136) bahwa melalui pembelajaran inquiry harus merancang pembelajaran yang melibatkan siswa secara aktif dimana pada proses awal pembelajaran guru memberi banyak bimbingan kemudian secara teratur mengurangi frekuensi bimbingan. Dengan demikian, siswa dapat menjadi penyelidik yang baik dan pengetahuan ilmiahnya dapat terpenuhi.

Model pembelajaran ini siswa menempatkan sebagai fokus utama dalam kegiatan pembelajaran dan siswa didorong agar lebih kreatif dalam memecahkan permasalahanpermasalahan yang dihadapinya. Permasalahan- permasalahan ini tentunya yang ada kaitannya antara materi yang diajarkan dengan kehidupan keseharian peserta didik. Di samping itu, guru sebagai fasilitator bertanggung jawab penuh dalam mengidentifikasi tujuan pembelajaran, struktur materi dan keterampilan dasar yang akan diajarkan. Kemudian membantu peserta didik untuk memecahkan masalah dalam pelaksanaan dan penerapan model pembelajaran inquiry.

Dalam penelitian ini terdapat perbedaan kemampuan berpikir kritis siswa yang diajarkan dengan model pembelajaran inquiry dan pembelajaran Konvensional. Berdasarkan hasil penelitian bahwa model pembelajaran inquiry lebih berpengaruh dari pada pembelajaran Konvensional yang terlihat jelas bahwa dari selisih nilai rata-rata kemampuan berpikir kritis siswa yang diajar dengan model pembelajaran inquiry dan pembelajaran konvensional.

Hal ini dikarenakan model pembelajaran inquiry adalah suatu rangkaian kegiatan pembelajaran yang melibatkan secara maksimal seluruh kemampuan peserta didik untuk mencari dan menyelidiki secara sistematis, kritis, dan logis sehingga mereka dapat menemukan sendiri pengetahuan, sikap dan keterampilan sebagai wujud adanya perubahan prilaku. Dalam hal ini pembelajaran inquiry merupakan kegiatan pembelajaran yang melibatkan secara maksimal seluruh kemampuan siswa untuk mencari dan menyelidiki sesuatu (benda, manusia atau pristiwa) secara sistematis, kritis, logis, analitis sehingga mereka dapat merumuskan penemuannya dengan penuh percaya diri (Nuriali, W., dkk, 2019). 
Selain itu peningkatan kemampuan berpikir kritis menggunakan model pembelajaran inquiry lebih baik karena model pembelajaran ini memiliki beberapa kelebihan yaitu 1) model pembelajaran inquiry (guided inkuiry) ini mampu membuat siswa menjadi lebih aktif, lebih terampil dan lebih kreatif dalam proses pembelajaran. Keaktifan seorang siswa pada pembelajaran sangat mempengaruhi hasil belajar siswa. 2) Memotivasi siswa untuk belajar dengan menyediakan peluang-peluang bagi mereka untuk membangun makna mereka sendiri dan mengembangkan pemahaman yang mendalam. 3) Model pembelajaran inquiry ini membantu siswa meningkatkan daya juang siswa dalam memecahkan suatu masalah.

Oleh karena itu model pembelajaran inquiry menciptakan kegiatan yang merangsang keingintahuan siswa yaitu dengan memberikan masalah yang berkaitan dengan kehidupan sehari-hari siswa, kerja kelompok, membuat karya atau laporan dan mempresentasikannya. Dengan kegiatan tersebut menjadikan model pembelajaran inquiry disukai oleh siswa sehingga siswa lebih termotivasi untuk mengikuti proses pembelajaran. Sedangkan pembelajaran konvensional adalah pembelajaran langsung yang lebih didominasi oleh guru yang menyebabkan siswa lebih banyak mendengar, menyimak dan menghafal dari pada menemukan sendiri suatu konsep, sehingga siswa sulit memahami materi yang diajarkan dan hanya aktif dalam mendengar penjelasan guru kemudian mencatat di buku apa yang disampaikan guru.

\section{Simpulan}

Berdasarkan hasil penelitian, maka dapat disimpulkan bahwa terdapat pengaruh penerapan model pembelajaran inquiry terhadap kemampuan berpikir kritis siswa pada tema Peristiwa dalam Kehidupan kelas VA SD Negeri 90 Kendari. Hal ini dapat dilihat dari nilai rata-rata posttest kemampuan berpikir kritis siswa pada tema Peristiwa dalam Kehidupan kelas VA SD Negeri 90 Kendari pada kelas eksperimen=70,94 dan kelas kontrol =59,69 maka kemampuan berpikir kritis siswa dengan penerapan model pembelajaran inquiry lebih tinggi dari pada rata-rata tes kemampuan berpikir kritis siswa dengan model pembelajaran konvensional. Dengan demikian penerapan model pembelajaran inquiry sangat membantu peserta didik dalam meningkatkan kemampuan berpikir kritis siswa dalam proses pembelajaran tema Peristiwa dalam Kehidupan kelas VA SD Negeri 90 Kendari

\section{Referensi}

Astuti, Dian. (2018). Pengaruh Model Pembelajaran Inquiry Terhadap Kemampuan Berpikir Kritis Siswa Pada Tema Organ Gerak Hewan dan Manusia Kelas Vc SDN 01 Baruga. Jurusan Pendidikan Guru Sekolah Dasar Fakultas Keguruan dan Ilmu Pendidikan Universitas Halu Oleo.

Dimyati \& Mudjiono. (2002). Belajar dan Pembelajaran. Jakarta: Rineka Cipta dan Depdikbud.

Hani Nur'Azizah, dkk. (2016). Pengaruh Model Pembelajaran Inquiry Terhadap Kemampuan Berpikir Kritis Siswa Pada Materi Energi Bunyi. Jurnal Program Studi PGSD Kelas UPI Kampus Sumedang Vol. 1, No. 1.

Hanifah, Ummu. (2017). Perbedaan Efektivitas Antara Penerapan Model Pembelajaran Discovery Dan Inquiry Ditinjau Dari Hasil Belajar IPA Siswa. ejurnalmitrapendidikan, Vol 1, No. 2, April 2017.92-104. http://www.ejurnalmitrapendidikan.com/index.php/e-jmp/article/view/60 
Hendracipta, Nana, Lukman Nulhakim, \& Agustini, Siti Mariam. (2017). Perbedaan Kemampuan Berpikir Kritis Siswa Melalui Penerapan Model Inkuiri Terbimbing Di Sekolah Dasar. JPSD Vol. 3 No. 2, September 2017. 215-227. http://jurnal.untirta.ac.id/index.php/jpsd/article/viewFile/2141/2704

Henok Siagian dan Zones Randy Simatupang. (2017). Pengaruh Model Pembelajaran inquiry terintegrasi Animasi Flash Terhadap Hasil Belajar Siswa pada Materi Pokok Fluida Dinamis. Jurnal Penelitian Bidang Pendidikan Volume 23(1):47-54, 2017. pISSN:0852-0151. e-ISSN :2502-7182

Lastriningsih, L. (2017). Peningkatan Berpikir Kritis dan Prestasi Belajar Melalui Metode Inquiry pada Siswa Kelas IV SD. Jurnal Prima Edukasia, 5 (1), 2017, 68-78. https://core.ac.uk/download/pdf/190366663.pdf

Nur’Azizah, Hani, Asep Kurnia Jayadinata, Gusrayani, Diah. (2017). Pengaruh Model Pembelajaran Inkuiri Terbimbing Terhadap Kemampuan Berpikir Kritis Siswa Pada Materi Energi Bunyi. Jurnal Pena Ilmiah: Vol. 1, No. 1 (2016). 51-60. https://ejournal.upi.edu/index.php/penailmiah/article/viewFile/2931/1958

Nuriali, W., Busnawir, B., Samparadja, H., \& Ili, L. (2019). Pengaruh Model Pembelajaran Inkuiri Terbimbing Terhadap Kemampuan Berpikir Kritis Matematika Ditinjau Dari Kemandirian Belajar Siswa SMK. Jurnal Pembelajaran Berpikir Matematika (Journal of Mathematics Thinking Learning), 3(2).

Sanderayanti, Dwi. (2015). Pengaruh Motivasi Berprestasi Dan Kemampuan Berpikir Kritis Terhadap Hasil Belajar Matematika Siswa Di SDN Kota Depok. Jurnal Pendidikan Dasar Volume 6 Edisi 2 Desember 2015. 222-231. http://journal.unj.ac.id/unj/index.php/jpd/article/view/484

Suhada, Hidayati. (2017). Model Pembelajaran Inquiry Dan Kemampuan Berpikir Kritis Terhadap Keterampilan Proses Sains Siswa Kelas V Pada Mata Pelajaran IPA. JPD: Jurnal Pendidikan Dasar. 13-24. DOI: doi.org/10.21009/JPD.082.02

Widdy S. Nugrah. (2018). Peningkatan Kemampuan Berpikir Kritis dan Penguasaan Konsep IPA Siswa SD Dengan Menggunakan Model Problem Based Learning. Jurnal Pendidikan Dasar p-ISSN 2085-1243 | e-ISSN 2579-5457 Vol. 10 No.2 Juli 2018 